\title{
TOWARD A STRATEGIC THEORY OF RISK PREMIUM: MOVING BEYOND CAPM
}

\author{
SAYAN CHATTERJEE \\ Case Western Reserve University \\ MICHAEL H. LUBATKIN \\ University of Connecticut \\ EM Lyon \\ WILLIAM S. SCHULZE \\ University of Connecticut
}

\begin{abstract}
We propose $\alpha$ framework of risk premium that offers $\alpha$ resolution to CAPM's challenge to the field of strategy. Our core assumption is that investors bear firm-specific risk because they are not as diversified and markets not as perfect as CAPM assumes. We therefore hypothesize that investors require lower risk premiums from firms that are able to reduce firm-specific risk, and we ground this prediction on theories from information economics, risk management, and strategy, as well as recent empirical challenges to CAPM.
\end{abstract}

The capital asset pricing model (CAPM) poses a strong challenge to the field of strategy that has remained unresolved since first noted by Bettis (1983). Our field's theory, research, and pedagogy are based on the intuition that management matters: firms, through calculated actions, can protect or isolate their earnings from market forces in ways that are valuable to investors. However, we lack a theoretical grounding for this intuition, particularly when it is placed under the lens of CAPM. Implicit to this model of asset pricing is the recommendation that managers focus on lowering their firm's beta (systematic) risk and not be concerned with firm-specific (unsystematic) risk. ${ }^{1}$ Herein lie two

All authors contributed equally to this work. We thank Jay Dial, Richard Dino, Kent Miller, Zeki Simsek, Robert Wiseman, Mark Yound, and the anonymous reviewers for their comments and suggestions on earlier drafts of this note.

${ }^{1}$ CAPM assumes that market equilibrium forces are paramount because markets collect and distribute all information quickly (efficiently), thoroughly (without imperfections), and at zero cost. CAPM also assumes that investors are fully (efficiently) diversified so that their investment in risky assets (including securities) captures the risk and return properties of the market portfolio (the index of all risky assets). It follows that, in a CAPM world, investors are concerned only about a firm's beta (systematic) risk, defined as the covari- dilemmas: first, reducing beta requires that managers do something they cannot-that is, reduce investors' exposure to macroeconomic uncertainties at a lower cost than what investors could transact on their own by modifying their investment portfolio; second, asking managers to downplay the importance of firmspecific risk is not only contrary to our field, it also tempts corporate bankruptcy (Bettis, 1983). Thus, CAPM is clearly at odds with strategic theory since it implies that managers should focus on that which they cannot influence, and should not be concerned with that which they can and, per strategic theory, should influence.

Therefore, we find it ironic that many strategy researchers, including two of the authors of this note, have used CAPM-derived measures of risk and return to examine investor reactions to a

ance of the returns to the security with those of the market portfolio, divided by the variance of the market portfolio. Beta defines a firm's risk premium (cost of equity) or the discount rate that is used by fully diversified investors to compute a firm's net present value. Since investors are only concerned about beta, they are not concerned with firmspecific (unsystematic) risk, which is defined as the variance in a security's returns that cannot be explained by movements in the market portfolio. 
wide variety of firm-specific actions and that McWilliams and Siegel (1997) recently have offered suggestions for their continued use. We say "ironic" because, by defining risk and return in a CAPM manner, our field has published findings that may be logically, if not empirically, flawed. Simply put, to test the hypothesis that management matters, our field unwittingly has borrowed a technique for inferring information from stock prices from a paradigm that assumes the alternative hypothesis.

In this note we propose a framework of risk premium that is consistent with the founding assumptions of strategy and that offers a resolution to CAPM's challenge. Our core assumption is that investors bear firm-specific risk because they are not as diversified and markets are not as perfect as CAPM assumes. We therefore hypothesize that investors require lower risk premiums from firms that are able to reduce firm-specific risk, and we ground this prediction on theories from information economics, risk management, and strategy, as well as recent empirical challenges to CAPM. We begin by reviewing these challenges and conclude with a research agenda for furthering our understanding of firm-specific risk, as well as with practical suggestions for those still interested in inferring information from stock prices using marketbased measures.

\section{RECENT CHALLENGES TO CAPM}

The utility of a theory rests on the veracity of its assumptions and its predictive validity. Regarding the former, scholars note that CAPM's simplifying assumptions do not conform to reality. For example, many have argued that most investors are not as fully diversified as CAPM presumes (e.g., Kadlec \& McConnel, 1994; Levy, 1978; Merton, 1987); Roll and Ross (1994) go further, claiming that a fully diversified portfolio is not possible to construct. Some express disenchantment with CAPM's assumption of static equilibrium, which Teece refers to as a "fictitious state" (1984: 90). Still others, studying the economics of information, reject CAPM's perfect market assumption on the grounds that markets are subject to a host of information asymmetries (Grossman \& Stiglitz, 1980; Stein, 1988, 1989). They contend that markets distribute information efficiently, but not thoroughly, and that these asymmetries explain why markets fail and organizations form (Arrow, 1974). These asymmetries also engender principle-agent problems, which agency theorists argue require carefully structured corporate governance mechanisms.

Of course, most theories are based on simplified assumptions, but this limitation is tolerated as long as it provides useful results. CAPM seems to also fall short here, for many empirical investigations conclude that investors care about more than just beta. Reinganum (1981), Lakonishok and Shapiro (1986), Merton (1987), Bhandari (1988), and Chan, Hamao, and Lakonishok (1991) question the predictive ability of beta, while in other studies researchers suggest that non-market (firm-specific) factors do a better job of predicting stock returns than just beta alone. For example, Levy (1978) found that a firm's unsystematic risk is a key predictor, Basu (1983) found that the earnings-to-price ratio explains stock returns at least as well as beta, Merton (1987) found both beta and firm-specific risk are important predictors, and others found the same true for leverage (Bhandari, 1988) and total variance in a firm's stock returns (Brown, Harlow, \& Tinic, 1993).

Some strategy studies present evidence that indirectly questions beta's predictive validity. Amit and Wernerfelt (1990) have observed that a firm's market value is inversely related to its level of unsystematic risk. Miller and Bromiley (1990), Cannella and Lubatkin (1993), and Lubatkin and Chatterjee (1994) all found that beta and unsystematic risk, as estimated from the market model, are correlated at .43, .32 , and .31, respectively $(p \leq .001$ ). Since the two risks are randomly distributed across firms, the two terms should not be correlated unless they have an overlapping component that is omitted from the model.

Arguably the most prominent challenge to the predictive validity of beta has come from Fama (1991, 1997) and Fama and French (1992, 1993. 1995, 1996). In brief, these researchers found that the market model explains a large percentage of the variation in stock returns but does a poor job of predicting stock returns. The former finding is based on a cross-sectional investigation of all publicly traded firms over a 30-year horizon, whereas the latter is based on a longitudinal investigation of those firms. These authors also found that the market model's accuracy sharply improved when it was expanded to include two 
firm-specific factors: firm size (market capitalization) and book-to-market value.

In other words, Fama, French, and other finance scholars (as previously cited) are concluding that investors consider more than how a firm's earnings covary with those of the market portfolio when determining a firm's risk premium and, thus, share price. Further, researchers in premier finance journals increasingly are using firm-specific measures to estimate longterm returns (e.g., Borber \& Lyon, 1997). The use of firm-specific measures, however, poses a challenge to CAPM because of their atheoretical nature. Fama and French refer to these measures as empirical anomalies, for they have no "special standing in asset-pricing theory" (1993: 3); however, Fama, French, and others include them in their estimates of $\alpha$ firm's risk premium for no other reason than that they seem to work.

Questions obviously remain as to precisely what investors care about and why. As we will discuss, firm-specific measures, such as firm size and book-to-market value, are too coarse grained and the reasons given for their inclusion in a model of asset pricing are too theoretically thin to adequately answer these "what and why" questions. ${ }^{2}$ In the next section we propose answers by using a strategic lens to examine some of CAPM's simplifying assumptions.

\section{A STRATEGIC CONCEPTUALIZATION OF RISK PREMIUM}

Regarding the what and why questions, we posit that investors care about firm-specific risk because most are not as fully diversified and markets are not as perfect as CAPM assumes. We draw support from information economics, which identifies asymmetries in the market for information and heterogeneous beliefs among market participants; from the resource-based view (RBV) of the firm, which identifies asymmetries in the markets for resources because they are lumpy, heterogeneous, and cannot be ac-

\footnotetext{
${ }^{2}$ Theory allows that size may grant $a$ firm a structurally advantaged position (Ravenscraft، 1983), thereby linking size to expected stock returns, but a variety of case studies and management theories point out the pitfalls of pursuing size for its own sake. As such, size holds little prescriptive value, and there are no solid theoretical reasons to include it when estimating a firm's risk premium. Similar statements can be made about book-to-market value.
}

quired costlessly; and from the industry structural view of strategy, which identifies asymmetries in the distribution of market power in both input and output markets.

We hypothesize that in a world of partial diversification and imperfect markets, investors are exposed to various classes of firm-specific risk, which we frame in Figure l. Like CAPM, our framework of risk premium consists of the sensitivity of a firm's expected returns to macroeconomic uncertainties (arrow $A$ in Figure 1). However, it also includes the sensitivity of a firm's returns to three additional classes of firmspecific risk that are omitted by CAPM, which we refer to as tactical, strategic, and normative risk. Tactical risk is rooted primarily in information asymmetries, strategic risk in imperfections in the resource and output markets, and normative risk in the forces that underlie institutional norms. Our framework also assumes an ongoing interplay between elements of a firm's activities and market forces. We open with a discussion of tactical risk.

\section{Tactical Risk}

Tactical risk is grounded on the assumption that information asymmetries make investors averse to earnings surprises. As such, investors will require lower risk premiums from firms who can minimize them. If tactics are firm-specific actions that are easily reversible (low opportunity costs), then tactical risk is the uncertainty in a firm's expected returns that managers can reduce. Firms use three types of activities to reduce tactical risk: financial tactics, hedges, and real options.

Financial tactics include earnings management, governance, and liquidity. The earnings management literature describes financial tactics that reduce information asymmetries existing between investors and management and that enhance the investors' ability to forecast earnings. This literature provides theoretical (Healy \& Palepu, 1995) and empirical (Chaney \& Lewis, 1995) evidence that firms, by developing a reputation with investors for minimizing earnings surprises, can reduce this source of uncertainty for investors and, in turn, reduce their risk premium. For example, this literature attributes GE's low risk premium partly to the way that it established rapport with investors and actively helped them forecast earnings estimates that 
FIGURE 1

A Dynamic Framework of a Firm's Risk Premium

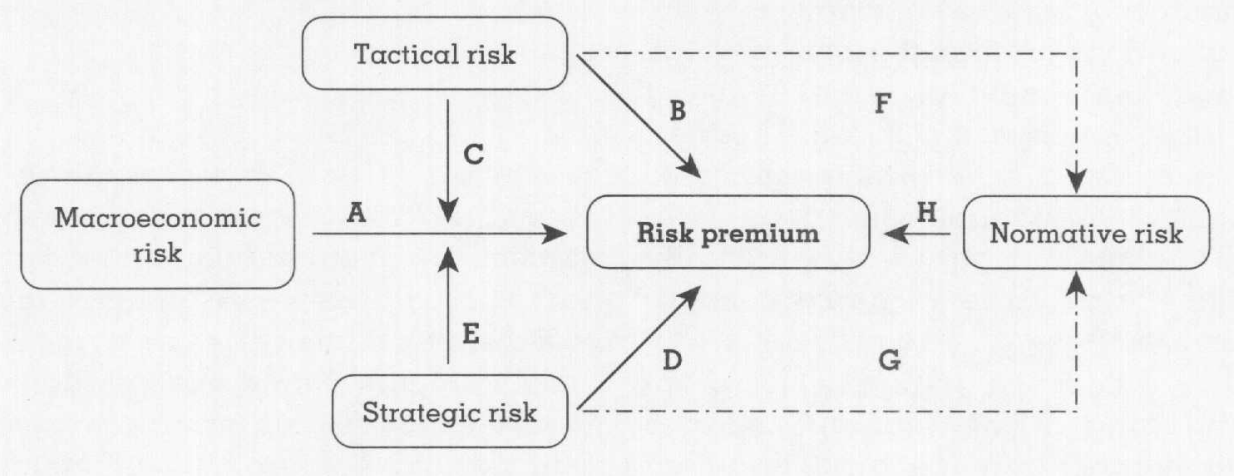

fall in a "very tight range" (Smith, Lipin, \& Naj, 1994). It also attributes Disney's low risk premium partly to its use of specific accounting and sales scheduling tactics to smooth earnings. ${ }^{3}$ Thus, we posit that earnings management serves to directly link firm-specific actions and risk premium (arrow B in Figure 1).

We find additional support for this direct link in the governance literature. This literature describes financial tactics, which reduce the uncertainty that is rooted in the different risk preferences held by investors and managers. For example, investors will raise a firm's risk premium should the firm try to limit market oversight by adopting such tactics as a poison pill. The literature also suggests that investors will lower a firm's risk premium, allow its management some discretion as to what information they publicly reveal, and even allow them voting control of the firm through dual class share-if the firm develops a reputation for achieving predictable growth (Gardiol, GibsonAnser, \& Tuchschmid, 1997; Lehn, Netter, \& Poulsen, 1990).

\footnotetext{
${ }^{3}$ For example, Jack Welch, the CEO of General Electric, has been quoted as saying that investors prize GE's ability "to deliver strong consistent earnings growth" (Smith et al., 1994: 1). Ben Zacks, of Zacks Investment Research, concurs; he notes that GE executives are very proactive in guiding analysts, leading to estimates that fall in a "very, very tight range" (Smith et al., 1994: Al). In a similar vein, Disney tries to smooth periods of earnings by rereleasing such classics as Snow White on videocassette; banks and insurance companies adjust their levels of reserves; many firms time writeoffs in ways that smooth earnings; and pharmaceutical firms use elaborate risk-management policies to reduce the impact of unanticipated failures (Smith et al., 1994).
}

Finally, the direct linkage between firmspecific actions and risk premium (arrow $B$ ) is suggested in the liquidity literature, which asserts that stock liquidity influences the uncertainty associated with on investor's potential cost of exiting from an investment. This literature purports that firms with few shares outstanding can lower their risk premium by splitting their stock (Gardiol et al., 1997).

The hedging literature describes tactics that indirectly link firm-specific actions and macroeconomic risk (arrow $\mathrm{C}$ in Figure 1). Specifically, this literature provides anecdotal (Froot, Scharfstein, \& Stein, 1994), theoretical (Smith, 1996; Smith \& Stulz, 1985), and empirical (Froot, Scharfstein, \& Stein, 1993) evidence that investors require lower risk premiums for firms that effectively use hedges. Hedges are contingent commitments that reduce the sensitivity of $\alpha$ firm's future earnings to cyclical and random variations in the price of those commodities the firm considers essential to its particular value chain. Put differently, hedges serve to partially buffer a firm's earnings from macroeconomic uncertainties that would otherwise add unexpected variability (surprises). Hedges include derivatives, swaps, futures contracts, and options. Most are intended to protect the firm against fluctuations in interest rates and foreign currencies. These financial hedges reduce the possibility of default while adding to a firm's debt capacity, thereby allowing a firm to better fund investments with internal capital (Chatterjee, 1991; Tufano, 1998). In contrast, nonfinancial hedges, such as futures contracts, grant the firm the right to take possession of commodities at $a$ later date. 
Finally, the real options literature describes tactics that also indirectly link firm-specific actions and macroeconomic risk (arrow C). The concept of real options originated in the strategy literature as an extension of options theory (Luehrman, 1998; Sanchez, 1993). Like hedges, real options provide a firm with a means to lower the likelihood of earnings surprises, without incurring the kind of significant opportunity costs that come with fixed resource commitments. As such, hedges and real options promote flexibility. Two traits distinguish real options from hedging. First, real options are contingent commitments made by a firm that grant it the right to secure noncommodity resources at a later date (Dixit \& Pindyck, 1994). Thus, real options cannot be valued using Black and Scholes' (1973) model, because noncommodities are not continuously traded. Second, real options deal with the cost of uncertain secular variations in the input and output markets that can threaten the long-term earnings generating potential of $\alpha$ firm's fixed commitments. As such, real options enable a firm "to operate at a higher level of uncertainty than they might otherwise be able to handle, given resource constraints" (McGrath \& Boisot, 1998: 4).

For example, a firm might opt to delay additional commitments to its production capacity until it gets a better read on the future demand by hiring part-time employees, adding an extra shift, and outsourcing for nonessential components. A firm might also use research consortia, technology alliances, experimental products, and other such probes that provide the possibility to make an informed judgment about an evolving technology ahead of its rivals (Brown \& Eisenhardt, 1998: 151). These probes not only reduce the sensitivity of the firm's committed resources to macroeconomic uncertainties but serve as an incubator to identify its next generation of strategic commitments.

In summary, multiple research streams lay the groundwork for understanding what firmspecific activities matter to investors and why they matter. We have noted empirical support for tactical risk from the research about earnings management, governance, liquidity, and hedging, and we have inferred support from the writings about real options. However, the management of tactical risk only explains how a firm can lower the variance in its expected earnings through minimizing earnings surprises; it is silent about how firms attain and sustain those expected earnings - the topic of the next section.

\section{Strategic Risk}

Strategic risk is driven primarily by imperfections in resource and output markets. Whereas tactics are about reducing information asymmetries through low-cost actions that are easily reversible, strategy is about making resource commitments before the relationship between these commitments and their potential performance outcomes are fully understood. If the goal of strategy is to use these commitments to attain and sustain competitive advantage, then strategic risks are rooted in the uncertainties of achieving that goal. Strategic risk, thus, is the probability that a firm can isolate its earnings from macroeconomic and industry-specific disturbances (arrows D and $\mathrm{E}$ in Figure 1).

Indeed, isolation is a core concept in the strategy literature (Barney, 1991; Rumelt, 1984). It and its analog, sustainable competitive advantage, assume imperfect markets and strategic choice-that is, firms have options to shape the market forces in their competitive arena and, in the process, gain advantage by leveraging existing market imperfections and/or creating new ones that favor them. As such, both concepts explain why some firms are able to partially buffer their earnings from the downside pressures of market forces in ways that are valuable to investors. They also explain why some firms are able to temporarily hold off market forces and pursue the kind of innovative actions that lead to better long-term solutions than would be possible with open market transactions. We therefore posit that investors require $\alpha$ lower risk premium for firms that achieve a degree of isolation from market forces because these firms can offer investors the promise of stable earnings and growth.

The strategy literature points to various determinants of strategic risk. Porter's (1980) "five forces" analysis suggests categories of strategic risk that are asymmetrically distributed in industries. These asymmetries enable structurally "advantaged" firms to partially isolate their earnings from direct attacks by rivals and from dilution by any of the other four forces. It follows that firms that can leverage and sustain their structural advantages will have lower risk pre- 
miums, all else being equal, because these firms have the market power to stabilize and grow their cash flows. For example, they might also "push" some of the downside threat of macroeconomic decline onto their less-advantaged rivals by extracting concessions from their key suppliers and distributors during times of recession and, thus, using them as buffers (Lubatkin \& Chatterjee, 1994). These actions therefore mitigate the sensitivity of the powerful firm's returns to this decline. Anecdotal examples about Procter \& Gamble and Coke and Pepsi illustrate these points. ${ }^{4}$

We deduce a second determinant of strategic risk from the RBV of the firm, in which the assumption is that resources are distributed heterogeneously and that valuable resources often are intangible and sometimes tacit. This makes a firm's resource-based advantages largely invisible to rivals, thus keeping them guessing about the firm's next move (Barney, 1991; Connor, 1991). It follows that resource-based advantages, like structural advantages, also help to isolate a firm from market pressures. For example, demand-side risk is reduced if a firm can offer customers higher quality and better service at lower cost than its rivals, for this capability enhances "buyer loyalty even during cyclical or seasonal downturns" (Porter, 1985: 120). Supply-side threats also can be reduced by establishing trust with suppliers, buyers, and joint venture partners (Gulati, 1994); by becoming an

\footnotetext{
${ }^{4}$ To understand what we mean by strategic risk, consider the actions taken by Procter \& Gamble (P\&G) to restructure the buyer-seller relationships in its industry. $P \& G$ set up a vendor replenishment system based on electronic data interchange with the large retailers of its products. Aside from providing a service for its retailers, the system allowed $P \& G$ to warehouse goods on the retailers' shelves. More important, it provided $P \& G$ with a way to partially isolate itself from the trend among large retailers, such as Wal-Mart and Target, who were using their buying power to force demand uncertainty onto suppliers. In essence, $P \& G$ identified the buyer power of the large retailers as a major source of its strategic risk. By moving before its rivals in establishing a clase relationship with buyers, P\&G was able to reduce this source of variance (making sales more certain) in ways that its less advantaged rivals and investors could not. Consider also the purposeful actions taken by Coke and Pepsi; each partially isolated its cash flows against the erosive forces of an increasingly competitive industry by forcing its lessadvantaged bottlers and rivals to serve as environmental buffers (HBS case \#5794143). As such, Coke and Pepsi affected their risk/return calculus in ways that investors could not, on their own, duplicate.
}

"employer of choice" (Ulrich \& Lake, 1991: 79); or by acquiring "factors of production at lower costs," operating "more efficiently, or both" (Amit \& Wernerfelt, 1990: 520).

We deduce a third determinant of strategic risk from the knowledge-based view (KBV) of the firm. The KBV asserts that the ability of firms to absorb, interpret, and commercialize critical information on a timely basis is also asymmetrically distributed (Lane \& Lubatkin, 1998). What sets knowledge apart from other resources is its highly fungible nature-its usefulness can extend "far beyond traditional product-marketbased views of industry definitions" (Sampler. 1998: 353). Firms such as Intel and Microsoft may show low risk premiums, in part, because their knowledge advantages allow them options to isolate their earnings through innovation. For example, they might leverage their advantages to expand their scope of activities into new markets, create asymmetries for future advantage, and partially isolate their earnings from technological obsolescence.

We deduce a fourth determinant of strategic risk from the strategic options literature (e.g., Sanchez, 1993). Some strategic options might have originated as "real" options, or contingent commitments, that the firm later committed to as market conditions changed. Strategic options, thus, are hard-to-reverse investments that a firm makes to mitigate specific sources of macroeconomic and industry-specific disturbances risk, for which other options, such as hedges, are not available (Miller, 1998). For example, a firm may diversify to reduce its exposure to a particular business or economic sector (Amit \& Livnat, 1988). ${ }^{5}$ Or a firm might acquire a key supplier to reduce the sensitivity of its cash flows to variability in the price of noncommodity inputs (Miller, 1998), as GM did when it acquired Al-

\footnotetext{
${ }^{5}$ The recent collapse of oil prices sharply affected the earnings of firms like Transocean Offshore who were involved in shallow-water drilling. However, Transocean mitigated the sensitivity of its cash flows to this macroeconomic risk by acquiring deep-water drilling capabilities in advance of the price collapse. Contracts for shallow-water drilling tend to be of a much shorter duration than contracts for deep-water drilling. Thus, by taking a real option in deep-water drilling, Transocean obtained a balance in its portfolio of contracts that allowed it to show smoother cash flows, regardless of fluctuations in the spot price of oil (Mack, 1996).
} 
can-the world's second largest producer of aluminum (The Economist, 1998).

\section{Normative Risk and Dynamic Forces}

We posit that the relationship between most tactical and strategic actions and a firm's risk premium is temporary; over time competition will erode the ability of both to reduce $\alpha$ firm's risk premium to the point that these actions become nothing more than a source of variance about some baseline level of firm-specific risk that, except for random variation, is similar for all firms (arrows $F$ and $G$ in Figure 1). This transformation occurs as activities lose their uniqueness and become institutionalized (Scott, 1995); embedded in the firm's market context (Dacin, 1997); or become "prerequisites for participation in the industry, but do not provide any significant competitor differentiation" (Hamel \& Prahalad, 1994: 206).

This is not to say that "norms" have no impact on a firm's risk premium. Following the adage "you don't get rewarded for following the rules, but you get punished for ignoring them," we posit that firms repeatedly $y^{6}$ failing to maintain the prerequisite norms are penalized with higher risk premiums. This is because "mismanagement" forces investors to bear additional risk without the promise of additional return. The financial accounting literature provides indirect support for this assertion by showing consistent evidence that investors react to the incremental information content of going-concern audit opinions (e.g., Jones, 1996). Therefore, we define normative risk as the risk premium that a firm incurs for failing to comply with any of its institutionally expected norms (arrow $\mathrm{H}$ in Figure 1).

Further, we posit that tactical activities are more susceptible to isomorphic pressures than are strategic activities and, thus, will be more rapidly transformed into normative activities. This is because the competencies that underlay most tactical activities are neither rare nor inimitable. Consequently, whatever risk premium advantages that $\alpha$ firm might derive from imple-

\footnotetext{
${ }^{6}$ We differentiate because occasional misfortune or windfall should have only a short-term effect upon asset prices and little, if any, effect on the risk premium, whereas this will not be true if the firm's activities among investors cause them to mistrust its managers.
}

mentation of tactical activities are not sustainable, because firms are able to outsource these activities to financial intermediaries. The exceptions are firms such as $3 \mathrm{M}$ and Charles Schwab. which show the uncanny ability to use real options and probes. Brown and Eisenhardt note that these two firms are successful at the "critical managerial issue at the edge of chaos," because they "figure out what to structure [or commit to], and as essential, what not to structure" (1998: 12).

Of course, even strategic activities are subject to these dynamic pressures. We deduce from Miller (1998) that the ability of a firm to sustain its isolation from market forces is itself influenced by macroeconomic variability; $a$ fall in foreign exchange rates can rapidly erode a firm's cost-leader position, technology change can erode the rareness or inimitability of a firm's resources and information, and so on. Competitive forces also can render sources of isolation less "strategic" as structural advantages are eroded, resources imitated, and knowledge disseminated. We therefore posit that market forces transform competitive advantages from firm-specific determinants of risk premium to institutional norms. We find indirect evidence for this speculation from Chan and Chen (1991) and Fama and French (1995). They observed that when a firm's current level of earnings do not appear sustainable, its risk premium increases long before its actual margins deteriorate.

Moreover, we posit that institutional norms may themselves be altered by shifts in the macroeconomic environment or by the introduction of new strategies. As such, activities that had become institutionalized might again be linked with a firm's strategic risk profile. Indeed, the adage of finding new uses for existing resources and capabilities or "changing the rules of the game" is fully consistent with conventional strategic thought but inconsistent with CAPM, which does not take into account this relationship or other such dynamic relationships when determining a firm's risk premium. In other words, institutional norms or the activities and skills that, over time, become prerequisites for participation in the marketplace are conceptually different from the variance in the market model's error term that CAPM defines as unsystematic risk. CAPM assumes that all firm-specific activities 
are unsystematic and, thus, not correlated with risk premium. In contrast, we posit that all firm-specific activities-even normsinfluence a firm's risk premium. Unlike tactical and strategic risk, however, norms impart a neutral influence on the risk premium unless mismanaged.

\section{IMPLICATIONS AND CONCLUSIONS}

Firms that investors perceive as being risky incur higher costs when raising capital-be it selling equity at lower prices or using debt with higher interest rates-and this has an adverse effect on the strategic opportunity set that the firm faces (Copeland \& Weston, 1991). Higher capital costs also discount future earnings more severely than lower capital costs, placing greater emphasis on short-term earnings. Finally, higher capital costs can put a firm at a competitive disadvantage when confronting rivals who have access to lower capital costs. In practical terms, management should pursue those actions that lower the level of their firm's risk in the eyes of the financial community.

What is less clear, however, is the exact nature of risk that managers should be concerned about. Bettis (1983) best articulated this confusion in his "Conundrum \#l: Unsystematic Risk Management." In brief, if "the continuous management of unsystematic [i.e., firm-specific] risk lies at the heart of strategic management" (1983: 408) but "the equity markets will not reward such managerial behavior" (1983: 409), then does strategy really make a meaningful difference? Armed with the findings from information economics, risk management, and strategy, as well as recent empirical challenges to CAPM, we argue that it does.

Specifically, we have proposed a framework of risk premium that posits that the concept is multivariate, comprising macroeconomic, tactical, strategic, and normative risks, and it is dynamic, involving an ongoing interplay between elements of the firm's activities and market forces. Our framework is consistent with the founding assumption of strategy that "management matters," while reaffirming what many finance scholars have already concluded: beta by itself is an unreliable proxy of $\alpha$ firm's risk premium. Whereas finance theorists have arrived at this conclusion largely through empirical discovery, our framework explains why this might be so. As such, it illustrates how contributions from strategic management and financial economics, when combined, can build a more conceptually complete asset pricing model. Finally, our framework has practical value, for it places the responsibility for risk management on managers, where the field of strategy has always felt it belongs.

Practical questions emerge from our framework. If beta is an unreliable proxy, what does that imply about the validity of the published management studies in which CAPM-based measures were used? If we are to continue to use market-based measures in a "post-beta" world, how should we compute them? In many strategy studies published during the past decade, researchers have used CAPM-based measures of risk (systematic and unsystematic) and return (Jensen's Alpha and event study's "abnormal returns") to examine investor reactions to a variety of firm-specific actions and unanticipated "events. "7 However, all CAPM-based measures, including the event-study measures that McWilliams and Siegel (1997) recommend for management research, are derived from estimates of beta. We stop short of challenging the interpretability of the findings from those studies. However, it is important to note that when there is a lack of correspondence between a concept and its mathematical formulation, as there is between the hypothesis that "management matters" and beta-based measures, it weakens the ability to test and build theory (Venkatraman, 1989). Further, researchers in finance are moving away from beta-based measures and using, instead, variants of Fama and French's three-factor model (e.g., Barber \& Lyon, 1997), parti-cularly when computing long-term stock performance.

Our recommendation is that researchers proceed with caution and not rely on a single formulation, particularly since the finance field has yet to sort through the various competing

\footnotetext{
${ }^{7}$ Strategy researchers have used the market model to investigate the performance and risk impact of $\alpha$ broad range of phenomena, including corporate diversification (Barton, 1988; Lubatkin \& Chatterjee, 1991, 1994), mergers and acquisitions (Chatterjee \& Lubatkin, 1990; Helfat \& Teece, 1987; Singh \& Montgomery, 1987), strategic alliances (Koh \& Venkatraman, 1991), executive succession (Freidman \& Singh, 1989; Lubatkin, Chung, Rogers, \& Owers, 1989), executive selection (Cannella \& Lubatkin، 1993), and competitive tactics (Bettis \& Weeks, 1987).
} 
methodologies. At a minimum, researchers who continue to use beta-based measures should test the sensitivity of their results with measures like market-adjusted returns (see Brown \& Warner, 1985) and total risk. Both are easy to compute and, more important, neither measure is based on CAPM's view of the world or on any assumption pertaining to the correct specification of the market model. ${ }^{8}$ Interestingly, total risk is the relevant risk measure in Markowitz's (1952) asset pricing model that preceded CAPM. ${ }^{9}$

Obviously, there is work to do. The link between strategic theory and risk premium involves an integration of theories that, to date, have not been developed adequately. Our framework serves as a useful starting point for the development of a theoretical model; it challenges CAPM by highlighting its omitted constructs, the range of firm-specific elements contained in those omitted constructs, and the extent to which those elements are involved in an ongoing state of interplay and change.

Like all frameworks, however, our framework can be criticized because its complexity makes it difficult to falsify. The next step for developing a strategic model of risk premium, therefore, is to provide more precise specifications of the included variables and more specific assertions about how those variables interact. Toward this end, we think that strategy scholars are well positioned to contribute, given our field's assumption of imperfect markets and our focus on

\footnotetext{
${ }^{8}$ Total risk is defined as the standard deviation in a firm's returns over some specified time period-say, 150 trading days. Market-adjusted returns are defined as the stock returns to the firm over some specified period of time, minus the returns to the market over the same period.

${ }^{9}$ Markowitz was the first to theorize a relationship between risk and return. According to his model of portfolio theory, investors should hold a diversified portfolio of securities that provide them with the highest level of return for $a$ given level of risk. In Markowitz's model, there are as many "efficient portfolios" as there are investor risk preferences, but all efficient portfolios must lie on the mean-variance investment frontiers where investors can get a higher return only by accepting a higher level of risk. Per Markowitz's model, management matters-that is, managers can create value for shareholders if they can find ways to reduce the firm's volatility of cash flows, or "total risk," without also reducing the expected value of those cash flows. CAPM then extended Markowitz's portfolio theory by demonstrating that, in equilibrium, there is only one efficient portfolio-the "market portfolio"-and it applies to all investors, regardless of their risk preferences. Thus, in equilibrium, investors care only about beta risk.
}

the firm-environment interface. Indeed, the distinctive role of strategy research among the social sciences has always been its capacity to integrate economic and behavioral theories with our own understanding of the firm in order to provide insights and guidance to individuals who manage them.

For example, research about earnings management, governance, and liquidity provides empirical evidence that links these activities to a firm's risk premium. Strategists can do the same with real options, the management of strategic risk, and the mismanagement of normative risk. Further, the financial risk management literature is silent about why it is mostly large firms that employ these tactics. Might the answer lie in a firm's level of diversification-like GE's-or in its geographic dispersion-like Coke's? Will the supply strategies that Wal-Mart and Dell have established become institutional norms in their respective industries? In addition, our proposed framework may prove useful in pointing out ways for strategy researchers to link behavioral theories on risk taking to a firm's risk premium. To date, behavioral theories (e.g., McNamara \& Bromiley, 1997; Wiseman \& Catanach, 1997) focus primarily on equating risk taking with strategic choice-not with the risk that concerns investors.

In conclusion, information economics, risk management, and strategic management hold a common view of competition where imperfections exist in the capital, factor, and product markets. We have proposed that this view offers one explanation as to why many researchers are finding that a firm's risk premium has firmspecific influences and, in turn, may resolve CAPM's vexing challenge to the field of strategy that was articulated by Bettis (1983) in his first conundrum.

\section{REFERENCES}

Amit, R., \& Livnat, J. 1988. Diversification strategies, business cycles and economic performance. Strategic Management Journal. 9: 99-110.

Amit, R., \& Wernerfelt, B. 1990. "Why do firms reduce business risk?" Academy of Management Journal, 33: 520533.

Arrow, K. J. 1974. The limits of organization. New York: Norton.

Barber, B. M., \& Lyon, J. D. 1997. Detecting long-run abnormal 
stock returns: The empirical power and specification of test statistics. Journal of Financial Economics, 43: 341372.

Barney. J. 1991. Firm's responses and sustained competitive advantage. Journal of Management, 17: 99-120.

Barton, S. L. 1988. Diversification strategy and systematic risk: Another look. Academy of Management Journal, 31: $166-175$.

Basu, S. 1983. The relationship between earnings yield, market value, and return for NYSE common stocks: Further evidence. Journal of Financial Economics, 12: 129-156.

Bettis, R. A. 1983. Modern financial theory, corporate strategy, and public policy: Three conundrums. Academy of Management Review, 8: 406-415.

Bettis, R. A., \& Weeks, D. 1987. Financial returns and strategic interaction: The case of instant photography. Strategic Management Journal, 8: 549-563

Bhandari, L. 1988. Debt/equity ratio and expected common stock returns: Empirical evidence. Journal of Finance, 43: 507-528.

Black, F., \& Scholes, M. 1973. The pricing of options and corporate liabilities. Journal of Political Economy, 81: 637-654.

Brown, K. C., Harlow, W. V., \& Tinic, S. M. 1993. The risk and required return of common stock following major price innovations. Journal of Financial and Quantitative Analysis, 28: 101-115.

Brown, S., \& Eisenhardt, K. 1998. Competing on the edge: Strategy as structured chaos. Boston: Harvard Business School Press.

Brown, S. J., \& Warner, J. B. 1985. Using daily stock returns. Journal of Financial Economics, 14: 3-31.

Cannella, A. A., Jr., \& Lubatkin, M. 1993. Succession as a sociopolitical process: Internal impediments to outsider selection. Academy of Management Journal, 36: 763-793.

Chan, K.-C., \& Chen, N.-F. 1991. Structural and return characteristics of small and large firms. Journal of Finance. 46: $1467-1484$.

Chan. L. K. C., Hamao, Y., \& Lakonishok، J. 1991. Fundamentals and stock returns in Japan. Journal of Finance, 46: $1739-1764$.

Chaney, P. K., \& Lewis, C. M. 1995. Earnings management and firm valuation under asymmetric information. Journal of Corporate Finance, 1: 319-345.

Chatterjee, S. 1991. Gains in vertical acquisitions and market power: Theory and evidence. Academy of Management Journal, 34: 436-448.

Chatterjee, S., \& Lubatkin, M. 1990. Corporate mergers, stockholder diversification, and changes in systematic risk. Strategic Management Journal, 1l: 255-268.

Connor, K. 1991. A historical comparison of resource based theory and five schools of thought within industrial organization economics: Do we have a new theory of the firm? Journal of Management, 17: 155-17l.

Copeland, T'. E., \& Weston, J. F. 1991. Financial theory and corporate policy. Reading, MA: Addison-Wesley.
Dacin, M. T. 1997. Isomorphism in context: The power and prescription of institutional norms. Academy of Management Journal, 40: 46-81.

Dixit، A. K., \& Pindyck, R. S. 1994. Investment under uncertainty. Princeton, NJ: Princeton University Press.

The Economist. 1998. Aluminum can-but will it? November 14: 76.

Fama, E. 1991. Efficient capital markets: II. Journal of Finance, 5: 1575-1616.

Fama, E. 1997. Market efficiency, long-term returns, and behavioral finance. Journal of Financial Economics, 49: 283-306.

Fama, E., \& French, K. 1992. The cross-section of expected returns. Journal of Finance, 47: 427-465.

Fama, E., \& French, K. 1993. Common risk factors in the returns on bonds and stocks. Journal of Financial Economics, 33: 3-56.

Fama, E., \& French, K. 1995. Size and book-to-market factors in earnings and returns. Journal of Finance, 50: 131-155.

Fama, E., \& French, K. 1996. Multifactor explanations of asset pricing anomalies. Journal of Finance, 51: 55-84.

Friedman, S. D., \& Singh, H. 1989. CEO succession and stockholder reaction: The influence of organizational context and event context. Academy of Management Journal, 32: $718-744$

Froot, K. A., Scharfstein, D. S., \& Stein, I. C. 1993. Risk management: Coordinating corporate investment and financial policies. Journal of Finance, 8: 1629-1658.

Froot, K. A., Scharfstein, D. S., \& Stein, J. C. 1994. A framework for risk management. Harvard Business Review, 72 (November-December): 91-98.

Gardiol, L., Gibson-Anser, R., \& Tuchschmid, N. S. 1997. Are liquidity and corporate control priced by shareholders? Empirical evidence from Swiss dual class shares. Journal of Corporate Finance, 3: 299-323.

Grossman, S. J., \& Stiglitz، J. E. 1980. On the impossibility of informationally efficient markets. American Economic Review, 70: 393-408.

Gulati, R. 1994. Does familiarity breed trust? The implications of repeated ties for contractual choice in alliances. Academy of Management Journal, 38: 85-112.

Hamel, G., \& Prahalad, C. K. 1994. Competing for the future. Boston: Harvard Business School Press.

Healy، P. M., \& Palepu, K. G. 1995. The challenges of investor communication. Journal of Financial Economics, 38: 111140 .

Helfat, C., \& Teece, D. 1987. Vertical integration and risk reduction. Journal of Low, Economics. and Organizations, 3(1): 47-67.

Jones, F. 1996. Information content of the auditor's going concern evaluation. Journal of Accounting and Public Policy, 15: 1-27.

Kadlec, G. B., \& McConnell, J. J. 1994. The effect of market segmentation and illiquidity on asset prices: Evidence from exchange listings. Journal of Finance, 49: 611-636. 
Koh, J., \& Venkatraman, N. 1991. Joint venture formations and stock market reactions: An assessment in the information technology sector. Academy of Management Journal, 34: 869-892.

Lakonishok, J., \& Shapiro, A. 1986. Systematic risk, total risk, and size as determinants of stock market returns. Journal of Banking and Finance, 10: 115-132.

Lane, P., \& Lubatkin, M. 1998. Relative absorptive capacity and interorganizational learning. Strategic Management Journal, 19: 461-478.

Lehn, K., Netter, J., \& Poulsen, A. 1990. Consolidating corporate control. Journal of Financial Economics, 27: 557-580.

Levy, C. 1978. Equilibrium in an imperfect market: A constraint on the number of securities in the portfolio. American Economic Review, 68: 643-658

Lubatkin, M. \& Chatterjee, S. 1991. The strategy-shareholder value relationship: Testing temporal stability across market cycles. Strategic Management Journal, 12: 25l270.

Lubatkin, M., \& Chatterjee, S. 1994. Extending modern portfolio theory into the domain of corporate diversification: Does it apply? Academy of Management Journal. 37: 109-136.

Lubatkin, M., Chung, K., Rogers, R., \& Owers, J. 1989. Succession effects in large corporations. Academy of Management Journal, 32: 47-68.

Luerhrman, T. M. 1998. Strategy as a portfolio of real options. Harvard Business Review, 76(September-October): 89-99.

Mack، T. 1996. Learning from experience. Forbes. 158(13): $102-108$.

Markowitz, H. 1952. Portfolio selection. Journal of Finance, 7: 77-91.

McGrath. R. G., \& Boisot, M. 1998. Corporate level "real options": The strategic equivalent of genetic variety. Working paper version 1.2, Columbia University, New York, NY.

McNamara, G., \& Bromiley, P. 1997. Decision making in an organization setting: Cognitive and organizational influences on risk assessment in commercial lending. Academy of Management of Journal, 40: 1063-1088.

McWilliams, A., \& Siegel, D. 1997. Event studies in management research: Theoretical and empirical issues. Academy of Management Journal, 40: 626-657.

Merton, R. 1987. Presidential address: A simple model of capital market equilibrium with incomplete information. Journal of Finance, 42: 483-510.

Miller, K. 1998. Economic exposure and integrated risk management. Strategic Management Journal, 19: 497-514.

Miller, K., \& Bromiley, P. 1990. Strategic risk and corporate performance: An analysis of alternative risk measures Academy of Management Journal, 33: 756-779.

Porter, M. 1980. Competitive strategy. New York: Free Press.

Porter, M. 1985. Competitive advantage. New York: Free Press.
Quinn, J. B. 1992. The intelligent enterprise: A new paradigm Academy of Management Executive, 6(4): 48-63.

Ravenscraft, D. 1983. Structure-profit relationships at the line of business and industry level. Review of Economics and Statistics, 65: 22-31.

Reinganum, M. 1981. Misspecification of capital asset pricing: Empirical anomalies based on earnings yields and market values. Journal of Financial Economics, 9: 19-46.

Roll, R., \& Ross, S. A. 1994. On the cross-sectional relation between expected returns and betas. Journal of Finance, 49: $101-121$.

Rumelt, R. 1984. Toward a strategic theory of the firm. In R. Lamb (Ed.), Competitive strategic management: 556570. Englewood Cliffs, NJ: Prentice-Hall.

Sampler, J. 1998. Redefining industry structure for the information age. Strategic Management Journal, 19: 343-356.

Sanchez, R. 1993. Strategic flexibility, firm organization, and managerial work in dynamic markets: A strategic options perspective. In P. Shivastrava, A. Huff, \& J. Dutton (Eds.), Advances in strategic management: 251-291. Greenwich, CT: JAI Press.

Scott, W. 1995. Institutional environments and organizations. Thousand Oaks, CA: Sage.

Singh, H., \& Montgomery, C. A. 1987. Corporate acquisition strategies and economic performance. Strategic Management Journal, 8: 377-386.

Smith, C. W., \& Stulz, R. M. 1985. The determinants of firms' hedging policies. Journal of Financial and Quantitative Analysis, 20: 391-405.

Smith, R. M. 1996. Rethinking risk management. Journal of Applied Corporate Finance, Fall: 8-24.

Smith, R., Lipin, S., \& Naj, A. 1994. Managing profits: How General Electric damps fluctuations of its annual earnings. Wøll Street Journal, November 3: Al.

Stein, J. C. 1988. Takeover threats and managerial myopia. Journal of Political Economy, 96: 61-80.

Stein, J. C. 1989. Efficient stock markets, inefficient firms: A model of myopic corporate behavior. Quarterly Journal of Economics, 104: 655-670.

Teece, D. 1984. Economic analysis and business strategy. California Management Review, 26(3): 87-110.

Tufano, P. 1998. Agency costs and risk management. Financial Management, 27(1): 67-77.

Ulrich, D., \& Lake, D. 1991. Organizational capability: Creating competitive advantage. Academy of Management Executive, 5(1): 77-92.

Venkatraman, N. 1989. The concept of fit in strategy research Towards verbal and statistical correspondence. Academy of Management Review, 14: 423-444.

Wiseman, R. M., \& Catanach, A. H., Jr. 1997. A longitudinal disaggregation of operational risk under changing regulations: Evidence from the savings and loan industry Academy of Management of Journal, 40: 799-830. 
Sayan Chatterjee is professor of policy in the Department of Marketing and Policy studies at the Weatherhead School of Management, Case Western Reserve University. $\mathrm{He}$ received his $\mathrm{Ph} . \mathrm{D}$. from the University of Michigan. His research interests are in corporate diversification, corporate governance, competitive strategy, and strategic risk management.

Michael H. Lubatkin is a professor of management and Ackerman Scholar at the University of Connecticut's School of Business and at EM Lyon, France. He received his Ph.D. from the University of Tennessee. Past chair of the BPS Division, his resecrch interests include issues about corporate diversification as they pertain to problems of core competency transfer between divisions and across national boundaries.

William S. Schulze is an assistant professor in the Management Department at the University of Connecticut's School of Business. He received his Ph.D. from the University of Colorado. His research interests include the application of organizational and economic theories of the firm to business-level strategy in general and family and other closely held businesses in particular. 